\title{
Distinct groups of plasmids correlated with bacteriocin production in Staphylococcus aureus
}

\author{
M. Giambiagi-Marval, M. A. Mafra, E. G. C. Penido and M. C. F. Bastos* \\ Instituto de Microbiologia, Universidade Federal do Rio de Janeiro, CCS, Bloco I, Cidade Universitária, \\ Ilha do Fundão, Rio de Janeiro, RJ 21.944, Brazil
}

(Received 11 December 1989; revised 1 April 1990; accepted 25 April 1990)

\begin{abstract}
The genetic basis of bacteriocin (Bac) production by six strains of Staphylococcus aureus was examined. Gene transfer experiments (in which the plasmids were tagged with the erythromycin resistance transposon $\mathrm{Tn} 551$ ) and plasmid-elimination experiments by growth at $43^{\circ} \mathrm{C}$ associated bacteriocin production with a particular plasmid in each strain. The Bac plasmids could be separated into two distinct groups: the first comprised plasmids larger than $40 \mathrm{~kb}$, which did not specify immunity to bacteriocins; the second comprised small plasmids (8.0-10.4 kb) which also specified immunity to bacteriocins. The sequence relations among the small plasmids (pRJ6, pRJ9, pRJ10 and pRJ11) were investigated by comparing restriction enzyme digest patterns and by hybridization. Plasmids pRJ10 and pRJ11 were indistinguishable and very closely related to plasmid pRJ9. Plasmid pRJ6, although different from the others, shared regions of sequence homology with them. No homology was found between plasmids pRJ6 or pRJ9 and the large Bac plasmids.
\end{abstract}

\section{Introduction}

The ability of various micro-organisms to inhibit the growth of other micro-organisms has long been recognized and sometimes attributed to metabolic waste products, lytic enzymes, antibiotics, bacteriophages or bacteriocins (Tagg et al., 1976). Bacteriocins are proteins, or proteins complexed with lipids and carbohydrates, which are lethal to other bacteria; their effect is generally limited to closely related species possessing specific receptor sites. Initial studies on bacteriocins were performed in Gram-negative bacteria, mainly in Escherichia coli and related species, and much knowledge has been accumulated concerning their chemistry, genetics and mode of action (Reeves, 1972; Hardy, 1975). In these organisms, bacteriocin production has been shown to be controlled by bacteriocinogenic (Bac) plasmids that often specify immunity to the bacteriocin produced. Production of bacteriocins and bacteriocinlike substances has been observed in Gram-positive bacteria, including staphylococci, and there have been various reports of the isolation, purification and biochemical properties of staphylococcal bacteriocins (Dajani \& Wannamaker, 1969; Gagliano \& Hinsdill, 1970; Jetten et al., 1972; Jetten \& Vogels, 1973; Dajani \&

Abbreviations: AMS, antimicrobial substance(s); ETA, ETB, exfoliative toxin type $\mathrm{A}, \mathrm{B}$.
Taube, 1974; Nakamura et al., 1983; Ersfeld-Dressen et al., 1984). In Staphylococcus aureus, bacteriocin production was correlated with the presence of a plasmid usually involved in type B exfoliative toxin production (Warren et al., 1974; O'Reilly et al., 1981; Masterson et al., 1983). These $42 \mathrm{~kb}$ plasmids were generally isolated from phage group II epidermolytic strains (Warren et al., 1975; Warren, 1980; O'Reilly et al., 1981). However, no detailed genetic and molecular characterization of bacteriocinogenic plasmids of $S$. aureus has been reported.

Here we describe genetic studies on the basis of bacteriocin production by six strains of $S$. aureus. Gene transfer experiments and plasmid-elimination experiments associated bacteriocin production with a particular plasmid in each strain. The plasmids involved in the production of these substances could be separated into two distinct groups: plasmids larger than $40 \mathrm{~kb}$; and small plasmids $(8 \cdot 0-10 \cdot 4 \mathrm{~kb})$. The sequence relations among the small Bac plasmids were investigated by comparing restriction enzyme digest patterns and by hybridization.

\section{Methods}

Bacterial strains and culture conditions. The strains used are listed in Table 1. Strains designated $\mathrm{H}$ were isolated from skin lesions, the noses or throats of outpatients of two children's hospitals in Rio de Janeiro. 
Table 1. Bacterial strains and plasmids

\begin{tabular}{|c|c|c|c|c|}
\hline Strain & Plasmid & $\begin{array}{l}\text { Size } \\
(\mathrm{kb})\end{array}$ & $\begin{array}{c}\text { Phenotype } \\
\text { associated } \\
\text { with plasmid* }\end{array}$ & $\begin{array}{l}\text { Source or } \\
\text { reference }\end{array}$ \\
\hline A53 & pRJ9 & $10 \cdot 4$ & $\mathrm{Bac}^{+} \mathrm{Imm}^{+}$ & \multirow{12}{*}{ This study } \\
\hline \multirow{4}{*}{ A65 } & pRJ10 & $10 \cdot 4$ & $\mathrm{Bac}^{+} \mathrm{Imm}^{+}$ & \\
\hline & pRJ15 & $27 \cdot 0$ & $\mathrm{Pc}^{r}$ & \\
\hline & $\mathrm{pRJ} 16$ & $4 \cdot 4$ & $T c^{r}$ & \\
\hline & pRJ17 & $1 \cdot 2$ & $?$ & \\
\hline A70 & pRJ6 & $8 \cdot 0$ & $\mathrm{Bac}^{+} \mathrm{Imm}^{+}$ & \\
\hline \multirow[t]{4}{*}{ A82 } & pRJ11 & $10 \cdot 4$ & $\mathrm{Bac}^{+} \mathrm{Imm}^{+}$ & \\
\hline & $\mathrm{pRJ} 18$ & $27 \cdot 0$ & $\mathrm{Pc}^{r}$ & \\
\hline & pRJ19 & $4 \cdot 5$ & $\mathrm{Cm}^{r}$ & \\
\hline & $\mathrm{pRJ} 20$ & $1 \cdot 2$ & $?$ & \\
\hline H55 & $\mathrm{pRJ} 12$ & $>40 \cdot 0$ & $\mathrm{Bac}^{+}$ & \\
\hline H56 & pRJ13 & $>40 \cdot 0$ & $\mathrm{Bac}^{+}$ & \\
\hline UT0101 & pRW0001 & $42 \cdot 0$ & $\mathrm{Bac}^{+} \mathrm{Tox}^{+}$ & Warren (1980) \\
\hline TC146 & pTC146 & $41 \cdot 0$ & $\mathrm{Bac}^{+} \mathrm{Tox}^{+}$ & O'Reilly et al. (1981) \\
\hline RN451 & - & - & - & Novick (1967) \\
\hline ISP479 & pRN3032 & $27 \cdot 5$ & $\mathrm{Cd}^{r} \mathrm{Em}^{\mathrm{r}} \mathrm{Tsr}$ & Pattee (1981) \\
\hline
\end{tabular}

* Bac, bacteriocin; Imm, immunity; Pc, penicillin; Tc, tetracycline; $\mathrm{Cm}$, chloramphenicol; Tox, exfoliative toxin; Cd, cadmium; Em, erythromycin; Tsr, thermosensitive for replication.

Strains designated A were isolated from commercial food. The bacteria were grown in CY medium (Novick, 1967) and stored at $-70^{\circ} \mathrm{C}$ until needed. Subcultures were made in CNE broth $[1.0 \%(\mathrm{w} / \mathrm{v})$ glucose, $0.3 \%(\mathrm{w} / \mathrm{v})$ yeast extract, $0.3 \%(\mathrm{w} / \mathrm{v})$ Casamino acids, $0.2 \%(\mathrm{w} / \mathrm{v})$ meat extract, $0.6 \%(\mathrm{w} / \mathrm{v}) \mathrm{NaCl}, \mathrm{pH} 7 \cdot 2)]$.

Corynebacterium fimi (NCTC 7547), rather than S. aureus, was used as an indicator strain for production of antimicrobial substance(s) (AMS), because of its greater sensitivity to staphylococcal AMS (Parker \& Simmons, 1959).

Assay for AMS production. The method described by Anthony et al. (1972) was used, with minor modifications. The strains were inoculated as a spot on the surface of a brain-heart infusion (BHI; Difco) agar plate. After $24 \mathrm{~h}$ at $37^{\circ} \mathrm{C}$, the bacteria were killed by exposure to chloroform vapour for $30 \mathrm{~min}$ and the plate sprayed with the indicator strain $(C$. fimi). AMS production was indicated by zones of inhibition around the colony after further incubation at $37^{\circ} \mathrm{C}$ for $18 \mathrm{~h}$. Strain UT010l $\left(\mathrm{Bac}^{+}\right)$was used as a positive control.

To determine the inhibitory spectrum of each AMS, strains representative of different species of Gram-positive and Gramnegative bacteria were tested as indicators. In these experiments the producer strains were grown on both BHI and CNE plates.

Characterization of $A M S$. The effects of heat and enzymes were determined by the methods of Gross \& Vidaver (1978). Plates with colonies of AMS producers were exposed to chloroform, incubated at 50,65 or $75^{\circ} \mathrm{C}$ for $60 \mathrm{~min}$, cooled to room temperature, and sprayed with the indicator strain (C. fimi).

The following enzymes were examined for their effect on AMS activity: trypsin (Sigma), pronase (Calbiochem), proteinase $\mathbf{K}$ (Boehringer Mannheim Biochemicals, BMB) and protease (type XXIII, from Aspergillus oryzae, Sigma) $\left(1 \mathrm{mg} \mathrm{ml}^{-1}\right.$, prepared in $0.05 \mathrm{M}$-Tris $\mathrm{pH} \mathrm{8.0,0.01} \mathrm{M-CaCl}$ ); RNAase A (Sigma) and DNAase I (BMB) $\left(1 \mathrm{mg} \mathrm{ml}{ }^{-1}\right.$, prepared in $0.05 \mathrm{M}$-Tris $\left.\mathrm{pH} 8.0,10 \mathrm{~mm}-\mathrm{MgSO}_{4}\right)$; and phospholipase $\mathrm{C}$ (Sigma) $\left(1 \mathrm{mg} \mathrm{ml}^{-1}\right.$, prepared in $0.1 \mathrm{M}$-phosphate buffer $\mathrm{pH} 7 \cdot 0)$. The enzymes $(40 \mu 1)$ were applied around the producer colonies after chloroform treatment. The plates were incubated at $37^{\circ} \mathrm{C}$ for a further $4 \mathrm{~h}$ and sprayed with the indicator strain (C. fimi).
The $M_{\mathrm{r}}$ values of AMS were estimated by the method of Joseph $e t$ al. (1983). The producer strains were grown on washed sterile dialysis membranes ( 12000 to 14000,6000 to 8000 , and $3500 M_{r}$ cutoff) on BHI agar. The producers were killed with chloroform, the membranes were removed, and the agar was sprayed with the indicator strain ( $C$. fimi).

Assay for exfoliative toxin $(E T)$ production. This test was done using culture supernatants which had been concentrated 20 -fold using Carbowax 6000. Double diffusion in Ouchterlony gels was employed (Arbuthnott \& Billcliffe, 1976), using type-specific anti-ET sera kindly provided by Dr Y. Piémont (Université Louis Pasteur, Strasbourg, France). Strain UT0101 was used as a positive control.

Screening for resistance determinants. This was done as described previously (Bastos \& Penido, 1981). The following antibiotic-containing discs (Difco) were used: chloramphenicol $(\mathrm{Cm}, 30 \mu \mathrm{g})$, erythromycin (Em, $15 \mu \mathrm{g})$, penicillin $\mathrm{G}(\mathrm{Pc}, 5 \mathrm{U})$, tetracycline $(\mathrm{Tc}, 30 \mu \mathrm{g})$, gentamicin $(\mathrm{Gm}, 10 \mu \mathrm{g})$, kanamycin $(\mathrm{Km}, 30 \mu \mathrm{g})$ and streptomycin $(\mathrm{Sm}, 10 \mu \mathrm{g})$.

Phage typing. The phage typing was carried out by Dr A. M. UthidaTanaka from the Staphylococcus aureus Phage Typing Laboratory, University of Ribeirão Preto, SP, Brazil, using the international basic set of typing phages.

Curing experiments. Growth of broth cultures at high temperature $\left(43^{\circ} \mathrm{C}\right.$ ) or with sodium dodecyl sulphate (SDS, $2 \mu \mathrm{g} \mathrm{ml}^{-1}$ ) was used to cure staphylococci of AMS production or drug resistance, as described previously (Bastos \& Penido, 1981).

Prophage and AMS induction. Induction of prophage and AMS production by ultraviolet (UV) irradiation was performed as described previously (Bastos et al., 1980).

Transduction. Transduction with phage $\phi 11$ was done as described previously (Bastos et al., 1980). Phage lysates were prepared either by UV induction of lysogenic strains or by infection of susceptible strains with wild-type $\phi 11$.

Plasmid DNA isolation. Cultures were grown in $2 \mathrm{ml} \mathrm{BHI} \mathrm{broth.} \mathrm{The}$ cells were harvested and washed once with TE buffer $(10 \mathrm{~mm}$-Tris pH 7.8, 1 mm-EDTA pH 7.5). The washed cells were resuspended in $900 \mu \mathrm{l}$ lysis buffer $[25 \%(\mathrm{w} / \mathrm{v})$ sucrose, $50 \mathrm{~mm}$-Tris $\mathrm{pH} 8.8$, $40 \mathrm{~mm}$-EDTA pH $7 \cdot 5,50 \mathrm{~mm}-\mathrm{NaCl})]$. Lysostaphin (Sigma) $(2 \mu \mathrm{l}$ of a $5 \mathrm{mg} \mathrm{m}^{-1}$ solution prepared in TE buffer) was added and the cells were incubated at $37^{\circ} \mathrm{C}$ for $30 \mathrm{~min}$. Then $100 \mu \mathrm{l}$ pronase $\left(10 \mathrm{mg} \mathrm{ml}^{-1}\right)$ was added. Lysis was completed by addition of $100 \mu \mathrm{LDS}(20 \%$, w/v). Following incubation at $37^{\circ} \mathrm{C}$ for $10 \mathrm{~min}$, the samples were heated at $65^{\circ} \mathrm{C}$ for $5 \mathrm{~min}$, then $\mathrm{KCl}$ was added to $0.4 \mathrm{M}$ and the samples were transferred to ice for a few minutes. The lysates were cleared by centrifugation at $12000 \mathrm{~g}$ for $10 \mathrm{~min}$. Nucleic acids were precipitated from the supernatant by adding 2 vols absolute ethanol followed by incubation at $-20^{\circ} \mathrm{C}$ for $18 \mathrm{~h}$. The DNA was pelleted by centrifugation at $12000 \mathrm{~g}$ for $10 \mathrm{~min}$. The DNA pellet was dried and dissolved in $100 \mu \mathrm{T}$ TE buffer.

Plasmid DNA for restriction endonuclease analysis and for nicktranslation reactions was prepared by caesium chloride/ethidium bromide density-gradient centrifugation of cleared lysates prepared as described by Novick et al. (1979b).

Restriction endonuclease analysis. The restriction endonucleases were purchased from Boehringer Mannheim Biochemicals and used as specified by the manufacturer.

Gel electrophoresis. Plasmids and restriction endonuclease digests of plasmid DNA were analysed by electrophoresis in $0.7-1.0 \%(\mathrm{w} / \mathrm{v})$ agarose horizontal slab gels and/or in $5.0 \%(\mathrm{w} / \mathrm{v})$ polyacrylamide vertical slab gels (Maniatis et al., 1982). In both cases the gel buffer and running buffer was $89 \mathrm{~mm}$-Tris, $89 \mathrm{~mm}$-boric acid, 2.5 mM-EDTA. Size 
standards for supercoiled plasmid DNA were plasmids from $E$. coli or $S$. aureus. Size standards for linear DNA fragments were bacteriophage $\lambda$ DNA cleaved with HindIII or with HindIII and EcoRI.

Hybridization. Southern blot hybridization was done as described previously (Bastos \& Murphy, 1988), except that the denatured DNA was transferred to Nytran membranes (Schleicher \& Schuell). Probe DNA was labelled by nick-translation as described by Maniatis et al. (1982).

\section{Results and Discussion}

\section{Production of antimicrobial substances}

Among 137 strains of $S$. aureus tested for AMS production, 15 showed inhibitory activity against $C$. fimi. The zones of inhibition produced by the $\mathrm{AMS}^{+}$strains isolated from food were consistently larger than those produced by the $\mathrm{AMS}^{+}$strains isolated from patients.

\section{Characterization of $\mathrm{AMS}^{+}$strains}

The $\mathrm{AMS}^{+}$strains belonged to phage group II (5 strains), phage group III (5 strains) and to phage groups I and III ( 2 strains). Three strains were not typable. Most strains carried resistance to more than one drug. None of these strains produced ETB, and only one strain (H30) expressed ETA.

All the $\mathrm{AMS}^{+}$strains harboured at least one plasmid (data not shown) and most carried more than one. Strains A53, A70, H55 and H56 carried a single plasmid.

\section{Elimination of AMS production by growth at high temperature}

Plasmid elimination experiments were performed in order to assign the AMS markers to plasmids. Ten of the $\mathrm{AMS}^{+}$strains did not lose their ability to produce AMS after growth at $43^{\circ} \mathrm{C}$. Elimination of $\mathrm{AMS}^{+}$was observed only with strains A65, A70, A82, H55 and H56.

\section{Characterization of the $A M S^{-}$derivatives}

The phage type and the susceptibility of the AMS derivatives to antibiotics were the same as those of their parental $\mathrm{AMS}^{+}$strains.

To obtain further evidence that AMS production was plasmid-determined, five cured variants from each of strains A65, A70, A82, H55 and H56 were screened for plasmids by agarose gel electrophoresis. Representative gels are shown in Fig. 1. In all cases, the loss of AMS production was accompanied by the loss of a plasmid. Thus strains A65 AMS- ${ }^{-}$A70 AMS ${ }^{-}$and A82 AMS- had lost plasmids of $10,7.5$ and $10 \mathrm{~kb}$, respectively (Fig. $1 a$, lanes B, D and F). The other plasmids found in strains
A65 AMS $^{-}$and A82 AMS- $^{-}$specify drug resistance (see below). Strains H55 AMS- and H56 AMS- had each lost a $>40 \mathrm{~kb}$ plasmid and were devoid of other plasmids (Fig. 1 $b$, lanes $\mathbf{B}$ and D). These findings suggest that the production of AMS by strains A65, A70, A82, H55 and H56 is controlled by plasmids.

\section{Sensitivity of $\mathrm{AMS}^{+}$and $A M S^{-}$strains to $\mathrm{AMS}$}

None of the $\mathrm{AMS}^{+}$strains was sensitive to the AMS that they produced (Table 2). The AMS produced by strain A70 inhibited the growth of all other AMS $^{+}$strains and their AMS- derivatives. The AMS produced by strains A53, A65 and A82 showed a similar spectrum of activity, being able to inhibit the growth of strains A70, H55 and H56 and their AMS $^{-}$derivatives.

In addition to loss of AMS production, the AMSderivatives of strains A65, A70 and A82 were susceptible to inhibition by the AMS produced by the parental strain, suggesting that the plasmids determined both the production of AMS and immunity to its action. On the other hand, cured derivatives of strains H55 and H56 retained resistance to the H55 and H56 AMS. Similar results have been reported for other strains of $S$. aureus (Gagliano \& Hinsdill, 1970; Jetten \& Vogels, 1973; Dajani \& Taube, 1974).

Properties of AMS from strains A53, A65, A70, A82, H55 and H56

Strain A53 was included in these studies because it contains a single plasmid. Although this strain could not be cured of AMS production, other experiments (see below) showed that this plasmid carries the genetic information for AMS production and immunity.

The inhibitory activity of these strains was not inducible by UV irradiation, nor could bacteriophages be detected in excised zones of inhibition when placed on lawns of sensitive staphylococci.

The AMS produced by all six strains were resistant to heat, retaining activity even after incubation at $75^{\circ} \mathrm{C}$ for 1 h. In addition, $\mathrm{NaOH}(0 \cdot 2 \mathrm{M})$, chloroform, RNAase $\mathrm{A}$ and phospholipase $\mathrm{C}$ had no effect on AMS activity. The AMS from strains A53, A65 and A82 was not affected by proteolytic enzymes. In contrast, activity of the AMS produced by strain A70 was markedly reduced or eliminated by incubation with protease from Aspergillus oryzae, trypsin, proteinase $\mathrm{K}$ or DNAase I, while the AMS produced by strains $\mathrm{H} 55$ and $\mathrm{H} 56$ were inactivated by protease and pronase.

The AMS produced by strains H55 and H56 were not dialysable even when a dialysis membrane with an $M_{\mathrm{r}}$ cutoff of 12000-14000 was used. The AMS produced by 

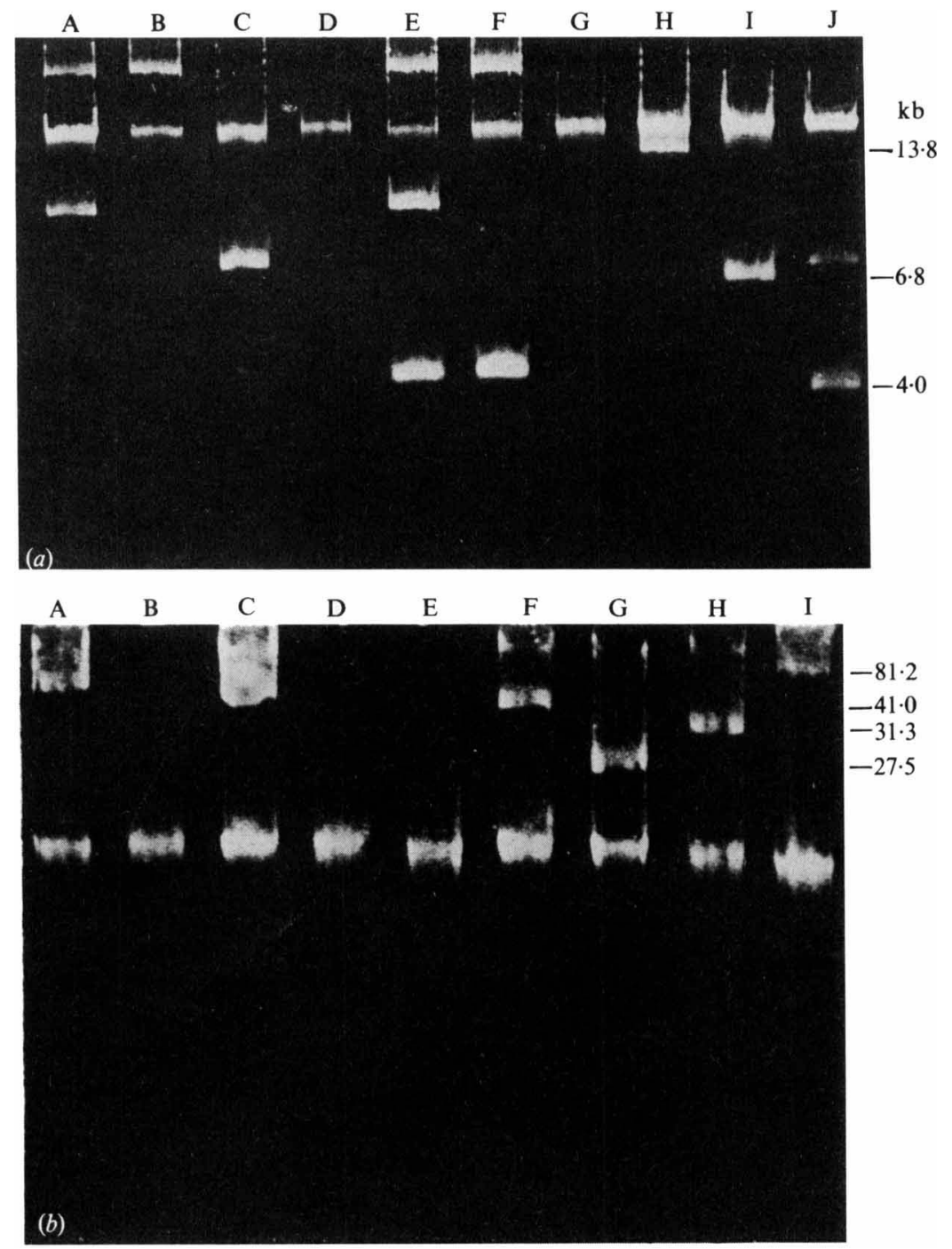

Fig. 1. Agarose gel electrophoresis of plasmid DNA isolated from $\mathrm{AMS}^{+}$strains of $S$. aureus and from AMS $^{-}$derivatives. The agarose concentration was $0.7 \%(\mathrm{w} / \mathrm{v})$. The lanes contained the following. (a) A, A65 AMS $^{+}$; B, A65 AMS $^{-}$; C, A70 AMS ${ }^{+}$; D, A70 AMS $^{-}$; E, A82 AMS $^{+}$; F, A82 AMS $^{-}$; G, RN451; H, RN4288 (pEM9609, 13.8 kb); I, RN2448 (pSA2100, $6.8 \mathrm{~kb}$ ); J, RN1777 (pS177, 4.0 kb). (b) A, H55 AMS $^{+}$; B, H55 AMS- ; C, H56 AMS+' D, H56 AMS-; E, RN451; F, TC146 (pTC146, 41.0 kb); G, RN11 (pI258, 27.5 kb); H, RN1465 (pII147, $31 \cdot 3 \mathrm{~kb}$ ); I, E. coli K12 711 (pEnt P307, 81.2 kb). The sizes $(\mathrm{kb})$ of the standard plasmids are indicated to the right.

Table 2. Sensitivity to $A M S$ of $A M S^{+}$strains and their cured $A M S^{-}$derivatives

These tests were repeated at least three times. ++ , zones of inhibition $>10 \mathrm{~mm}$; + , zones of inhibition $\leqslant 10 \mathrm{~mm}$; - , no inhibition.

\begin{tabular}{lcccccc}
\hline \hline \multirow{7}{*}{$\begin{array}{l}\text { Indicator } \\
\text { strain }\end{array}$} & A53 & A65 & A82 & A70 & H55 & H56 \\
\cline { 2 - 7 } & AMS from \\
\hline C. fimi & ++ & ++ & ++ & ++ & + & + \\
A53 AMS & - & - & - & + & - & - \\
A65 AMS & - & - & - & + & - & - \\
A65 AMS & ++ & ++ & ++ & + & - & - \\
A82 AMS & - & - & - & + & - & - \\
A82 AMS & ++ & ++ & ++ & + & - & - \\
A70 AMS & + & + & + & - & - & - \\
A70 AMS & + & + & + & + & - & - \\
H55 AMS & ++ & ++ & ++ & + & - & - \\
H55 AMS & ++ & ++ & ++ & + & - & - \\
H56 AMS & ++ & ++ & ++ & + & - & - \\
H56 AMS & ++ & ++ & ++ & + & - & - \\
\hline \hline
\end{tabular}

strains A53, A65, A70 and A82 were dialysable when a dialysis membrane with an $M_{\mathrm{r}}$ cutoff of $12000-14000$ was used, being retained by membranes with a 6000-8000 $M_{\mathrm{r}}$ cutoff.

These preliminary results showed that these AMS are a heterogeneous group of substances with properties similar to AMS characterized by other authors (Gagliano \& Hinsdill, 1970; Rogolsky \& Wiley, 1977; Nakamura et al., 1983). The AMS produced by strains A70, H55 and H56 were inactivated by proteolytic enzymes and are typical bacteriocins (Tagg et al., 1976). The bacteriocin produced by strain A70 is a protein of $M_{\mathrm{r}} 6000-14000$ and is sensitive to DNAase I, like a bacteriocin produced by a strain of Rhizobium trifolii (Schwinghamer, 1975). The $M_{\mathrm{r}}$ of the bacteriocin produced by strains $\mathrm{H} 55$ and H56 is higher than 14000 . The AMS produced by strains A53, A65 and A82 also have $M_{\mathrm{r}}$ values in the range $6000-14000$. However, they are resistant to proteolytic 


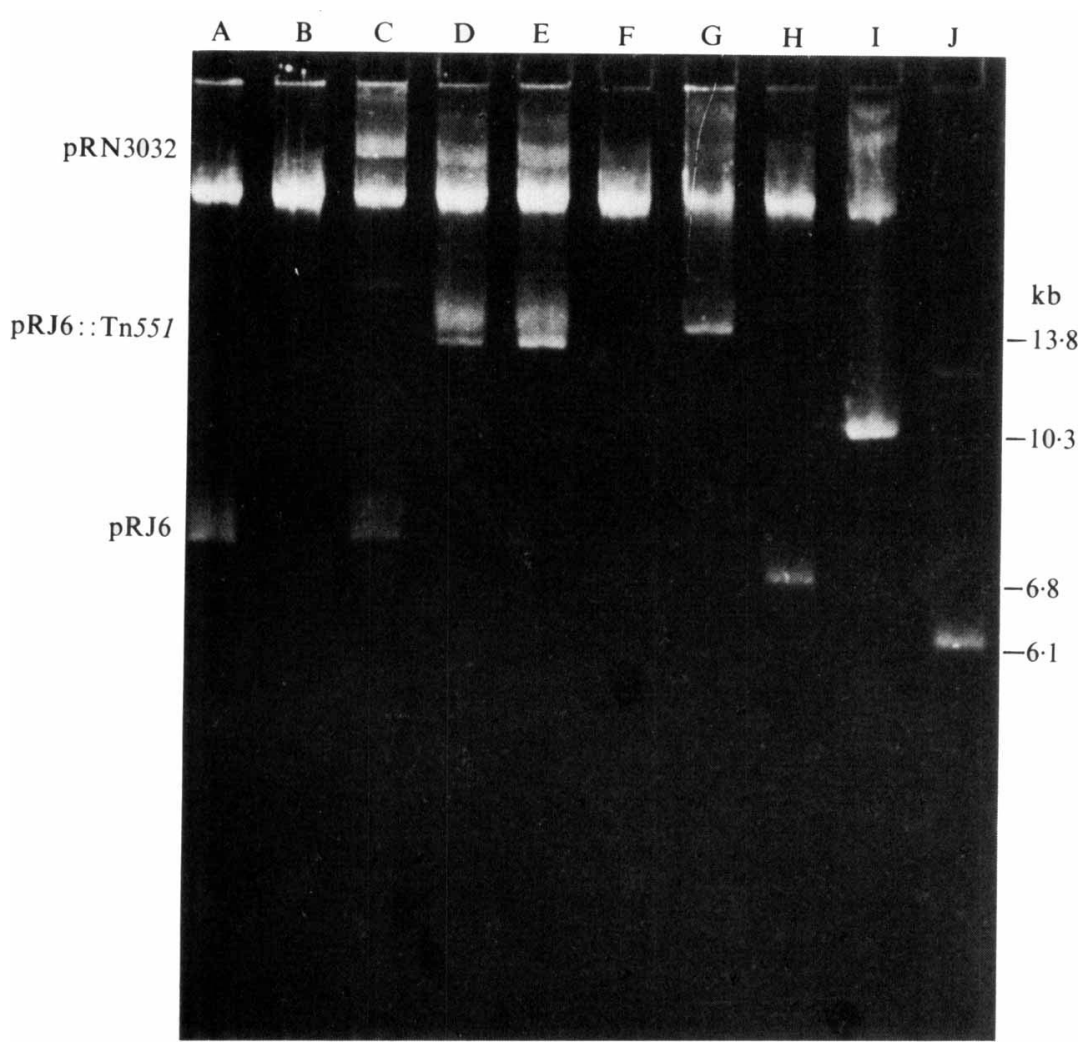

Fig. 2. Agarose gel electrophoresis of plasmid DNA isolated from $S$. aureus strain A70 and from transductants. The agarose concentration was $0.7 \%(w / v)$. Lanes contained: A, A70(pRJ6); B, RN451; C, $\mathrm{Em}^{r} \mathrm{Cd}^{r} \mathrm{Bac}^{+}$transductant derived from A70(pRJ6/pRN3032); D, $\mathrm{Em}^{\mathrm{r}} \mathrm{Cd}^{\mathrm{s}} \mathrm{Bac}^{+}$derivative of A70 harbouring pRJ6::Tn551; E, RN451 carrying

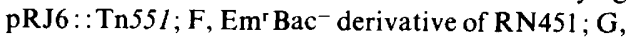
RN4288 (pEM9609, 13.8 kb); H, RN2448 (pSA2100, $6.8 \mathrm{~kb}$ ); I, E. coli HB101 (pSA30, 10.3 kb); J, E. coli $\mathrm{K} 12$ (pGR113, 6.1 kb) (chromosomal DNA is not seen in this lane because it contained plasmid DNA purified by $\mathrm{CsCl}$ /ethidium bromide density-gradient centrifugation). The sizes (kb) of the standard plasmids are indicated to the right. enzymes and can be considered to be bacteriocin-like substances.

The inhibitory effect of these bacteriocins and bacteriocin-like substances was not restricted to staphylococci and C. fimi: many other Gram-positive bacteria, but none of the Gram-negative bacteria tested, were sensitive (data not shown). This is a common feature of bacteriocins of Gram-positive organisms, including staphylococcins (Dajani et al., 1970; Gagliano \& Hinsdill, 1970; Jetten \& Vogels, 1972). C. fimi and Bacillus megaterium were the best indicators for the bacteriocins produced by strains A53, A65, A70 and A82, whereas C. fimi and Micrococcus sp. were more sensitive indicators for those produced by strains $\mathrm{H} 55$ and $\mathrm{H} 56$.

\section{Gene transfer experiments}

To obtain further evidence for the involvement of the small plasmids in bacteriocin production, strains A53 and $A 70$ were used in gene transfer experiments. Strains A53 and A70 carry single plasmids, pRJ9 $(10 \mathrm{~kb})$ and pRJ6 (7.5 kb), respectively. Plasmid-elimination experiments suggested that pRJ6 mediates bacteriocin production. However, plasmid pRJ9 could not be eliminated from strain A53. Since neither plasmid carried a readily selectable marker, the plasmids were tagged with Tn551.
This $5 \cdot 2 \mathrm{~kb}$ transposon specifies resistance to Em and other macrolide antibiotics in $S$. aureus; it can transpose to many different sites in the $S$. aureus chromosome and in plasmids (Novick et al., $1979 a$; Pattee, 1981). Plasmid pRN3032, a temperature-sensitive $\mathrm{Cd}^{\mathrm{r}}$ plasmid that carries $\mathrm{Tn} 551$, was transferred to strains $\mathrm{A} 70$ and $\mathrm{A} 53$ by transduction from ISP479, selecting for $\mathrm{Em}^{r}$ and $\mathrm{Cd}$. Strains carrying pRN3032 and pRJ6 or pRJ9 were grown at $43^{\circ} \mathrm{C}$ (the nonpermissive temperature for pRN3032), in the presence of Em. Em ${ }^{r}$ colonies which were $\mathrm{Cd}^{\mathrm{s}}$ were identified. The stable maintenance of $\mathrm{Em}^{\mathrm{r}}$ was indicative of $\mathrm{Tn} 551$ transposition either into the chromosome or into a plasmid. Plasmid DNA was isolated from $\mathrm{Em}^{\mathrm{r}} \mathrm{Cd}^{\mathrm{s}}$ colonies that were $\mathrm{Bac}^{+}$and the pRJ6 or pRJ9 derivatives carrying Tn551 were presumptively identified by an increase in size. Plasmids pRJ6::Tn551 and pRJ9::Tn551 were transduced into the plasmid-free strain RN451, selecting for $\mathrm{Em}^{\mathrm{r}}$.

In experiments with $A 70(\mathrm{pRJ} 6)$, seven of $22 \mathrm{Em}^{\mathrm{r}} \mathrm{Cd}^{\mathrm{s}}$ colonies had lost both pRJ6 and pRN3032 and carried a plasmid of about $13 \mathrm{~kb}$, corresponding to the sum of pRJ6 $(7.5 \mathrm{~kb})$ and Tn551 (5.2 kb) (Fig. 2, lane D). Plasmid pRJ6: : Tn551 was transduced into RN451, and 86 of $87 \mathrm{Em}^{\mathrm{r}}$ transductants were also $\mathrm{Bac}^{+} \mathrm{Imm}^{+}$and contained pRJ6::Tn551 (Fig. 2, lane E). The single $\mathrm{Em}^{\mathrm{r}} \mathrm{Bac}^{-}$transductants had no plasmid DNA (Fig. 2, lane F). Similar results were obtained for strain A53 
carrying both pRJ9 and pRN3032 (data not shown). These results confirmed the involvement of plasmids pRJ6 and pRJ9 in bacteriocin production by strains A70 and A53.

Strain RN451 carrying pRJ9::Tn551 was immune to the bacteriocin-like substances produced by strains $A 65(\mathrm{pRJ} 10)$ and $\mathrm{A} 82(\mathrm{pRJ} 11)$, indicating that bacteriocin immunity is plasmid-controlled in strain A53. This is consistent with the observation that strains A65 and A82, but not their cured derivatives, were immune to the bacteriocin specified by plasmid pRJ9 (Table 2).

Curing drug resistance determinants from strains $A 65$ and A82

Strains A65 and A82 express resistance to $\mathrm{Pc}, \mathrm{Sm}$ and Tc and to $\mathrm{Pc}, \mathrm{Sm}$ and $\mathrm{Cm}$, respectively. Both strains harbour at least three plasmids (Fig. $1 a$, lanes A and E). The $10 \mathrm{~kb}$ plasmids are thought to be responsible for the production of the bacteriocin-like substances. To obtain strains carrying only the Bac plasmids, strains A65 and A82 were cured of $\mathrm{Pc}$ and $\mathrm{Tc}$ or $\mathrm{Pc}$ and $\mathrm{Cm}$ resistances, respectively, either by growth in broth with SDS or by growth at $43{ }^{\circ} \mathrm{C}$. These curing experiments indicated (data not shown) that a $27 \mathrm{~kb}$ plasmid probably determined resistance to $\mathrm{Pc}$, and that resistance to $\mathrm{Tc}$ or $\mathrm{Cm}$ was probably determined by $4.4-4.5 \mathrm{~kb}$ plasmids. The size of the plasmids responsible for drug resistance in these strains agrees with other reports (Novick \& Bouanchaud, 1971; Chopra et al., 1973).

The $\mathrm{Pc}^{\mathrm{s}} \mathrm{Tc}^{\mathrm{s}}$ derivatives of strain $\mathrm{A} 65$ and the $\mathrm{Pc}^{\mathrm{s}} \mathrm{Cm}^{\mathrm{s}}$ derivatives of strain A82 still contained a small cryptic plasmid ( $1.2 \mathrm{~kb})$ (Fig. 4) not detected in the gel shown in Fig. 1.

Attempts to cure strains $\mathrm{A} 65$ and $\mathrm{A} 82$ of $\mathrm{Sm}^{\mathrm{r}}$ were unsuccessful.

\section{Restriction endonuclease analysis of the small Bac plasmids}

The immunity experiments and characterization of bacteriocins suggested that at least two distinct antagonistic substances were produced by the strains harbouring small Bac plasmids. Plasmid pRJ6 represents the first group and plasmids pRJ9, pRJ10 and pRJ11 form the second one.

In order to compare the structures of these plasmids, purified DNA was analysed by restriction endonuclease cleavage and by gel electrophoresis. A physical map was constructed for pRJ6 (Fig. 3). pRJ6 had no sites for XhoI, BamHI, HaeIII, KpnI, SmaI and BstEII. There are two

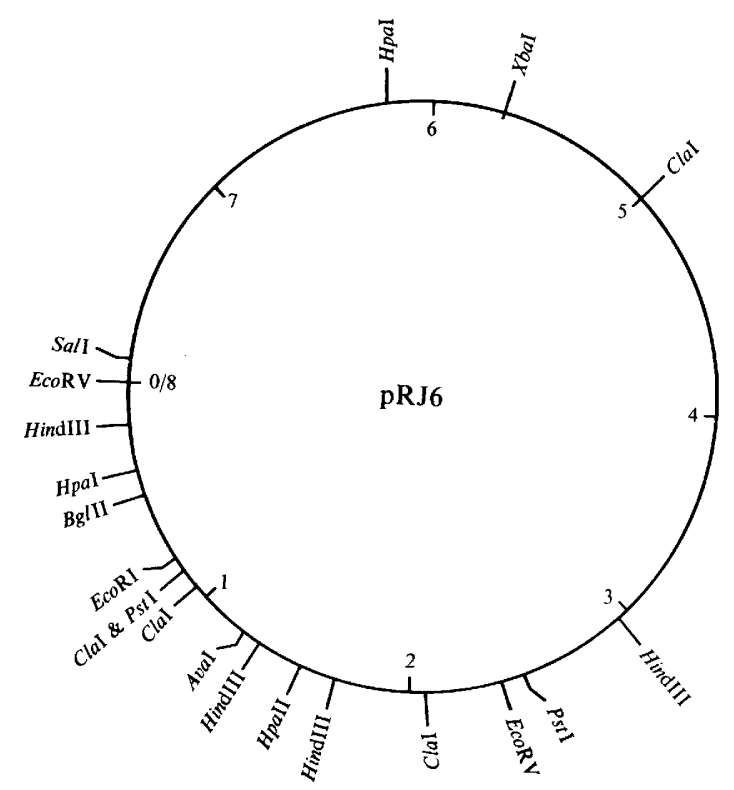

Fig. 3. Restriction map of pRJ6. The reference point of the map is one of the EcoRV sites. The distances are given in $\mathbf{k b}$.

restriction sites (one for Pst $\mathrm{I}$ and one for $C l a \mathrm{I}$ ) around coordinate $0 \cdot 8$, but their exact position could not be determined.

Cleavage of plasmids pRJ9, pRJ10 and pRJ11 with EcoRV, ClaI, Pst I, HindIII (Fig. 4) and HpaI (data not shown) resulted in the same banding patterns. The plasmids had no sites for $X h o \mathrm{I}$, BamHI, BstEII and $X b a \mathrm{I}$. However, some restriction site polymorphisms were also observed: pRJ 10 and pRJ11 had a single site for EcoRI which was absent from pRJ9, while pRJ9 had a single site for $B g l \mathrm{II}$ which was absent from pRJ10 and pRJ11. These data indicate that $\mathrm{pRJ} 10$ and $\mathrm{pRJ} 11$ are probably identical, and that they are very similar to pRJ9, but different from $p R J 6$. This confirms the relatedness of pRJ9, pRJ10 and pRJ11 suggested by the crossimmunity data and by the properties of the bacteriocinlike substances specified by them.

The sizes of the four plasmids were estimated from the sizes of the fragments generated by digestion with restriction enzymes. Plasmid pRJ6 was $8.0 \mathrm{~kb}$, while plasmids pRJ9, pRJ10 and pRJ11 were $10.4 \mathrm{~kb}$, a little larger than the sizes estimated from the data in Fig. 1.

\section{Hybridization analysis}

The relationship between the Bac plasmids was also investigated by Southern hybridization experiments with total plasmid DNA from all $\mathrm{Bac}^{+}$strains, including the reference strains TC146 and UT0101, using pRJ6 and pRJ9 as probes. 


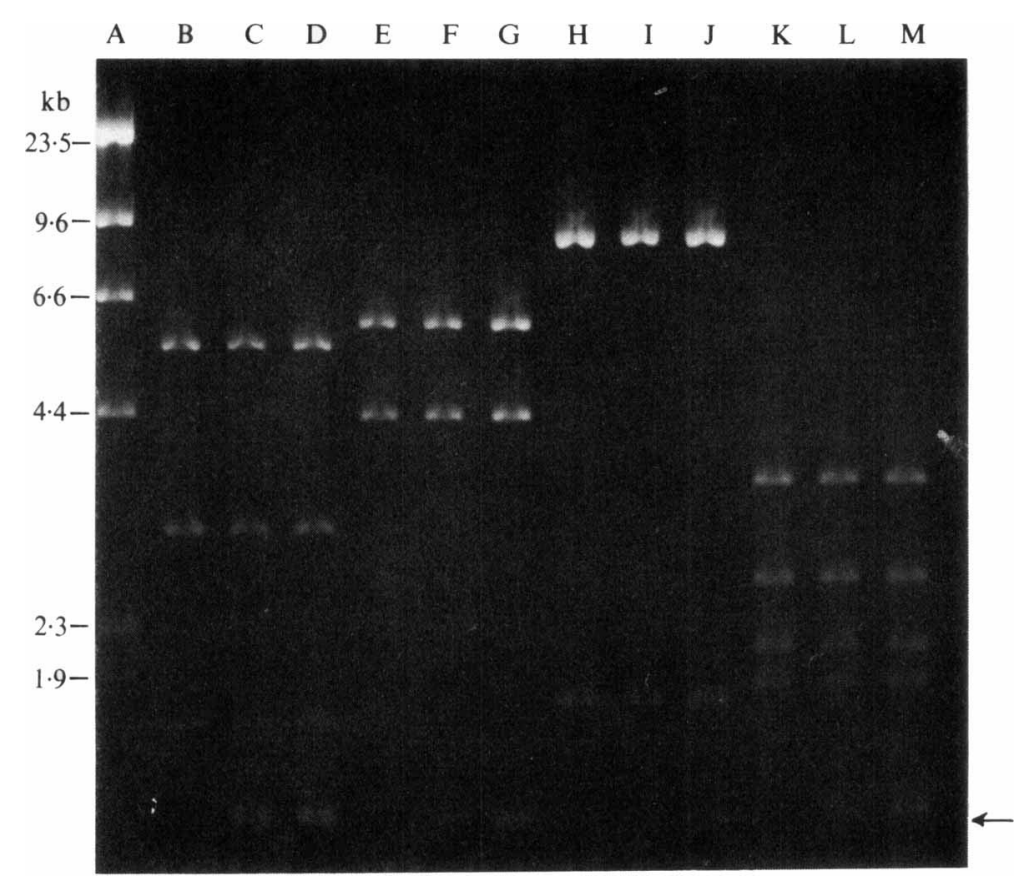

Fig. 4. Agarose gel electrophoresis $(0.7 \%$ agarose $)$ of purified DNA of pRJ9 (lanes B, E, H and K), pRJ10 (lanes C, F, I and L) and pRJ11 (lanes D, G, J and M) cleaved with EcoRV (lanes B-D), ClaI (lanes E-G), Pst I (lanes $\mathrm{H}-\mathrm{J}$ ) or HindIII (lanes $\mathrm{K}-\mathrm{M}$ ). Lane A contains bacteriophage $\lambda$ DNA cut with HindIII; the sizes $(\mathbf{k b})$ of the standard fragments are indicated on the left. The arrow at the bottom of the gel indicates different forms of a previously undetected cryptic plasmid present in strains A65 and A82.
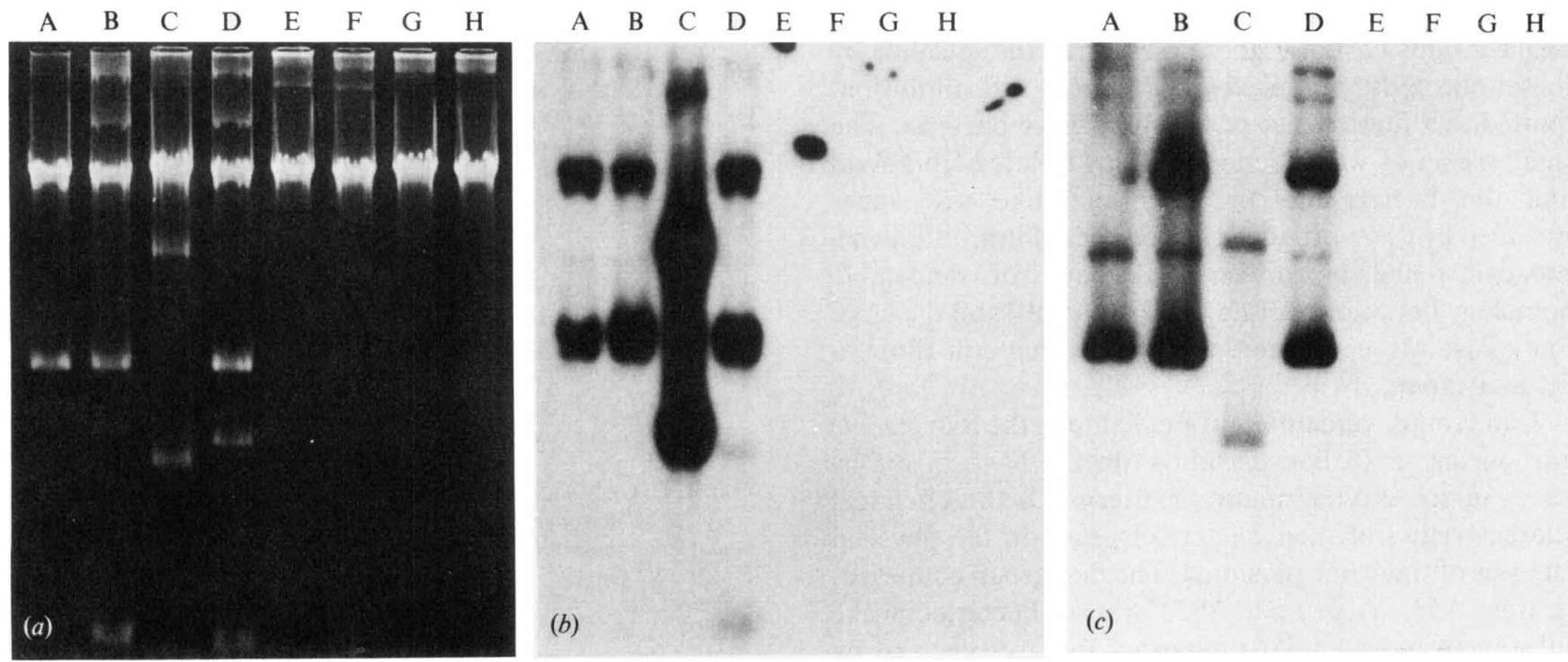

Fig. 5. DNA-DNA hybridization analysis of Bac plasmids. Undigested plasmid DNA samples were separated on a $0.7 \%(w / v)$ agarose gel, transferred to a Nytran membrane and hybridized to ${ }^{32}$ P-labelled pRJ6 (b) or pRJ9 (c) DNA. ( $a$ ) Photograph of ethidium bromidestained agarose gel. Lanes contain DNA isolated from the following strains: A, A53; B, A65; C, A70; D, A82; E, UT0101; F, TC146; G, H55; H, H56.

When pRJ6 was used as probe, the distribution of radioactivity coincided with the distribution of the fluorescent bands seen in the ethidium-bromide-stained agarose gels and corresponded to the open circular (OC) and supercoiled (SC) forms of the Bac plasmids carried by strains A53, A65 and A82 (Fig. 5b, lanes A, B and D). pRJ6 also showed much weaker homology with the $\mathrm{Cm}^{\mathrm{r}}$ plasmid carried by strain A82 (lane D). The nature of the sequence homology between pRJ6 and the $\mathrm{Cm}^{\mathrm{r}}$ plasmid is unknown. No hybridization was observed between pRJ6 and the large Bac plasmids carried by strains UT0101, TC146, H55 and H56 (Fig. 5b, lanes E, F, G and $H$ ), or to the penicillinase plasmids and $T \mathrm{C}^{\mathrm{r}}$ plasmid carried by strains A82 and/or A65 (lanes D and B). 
Similar results were obtained when pRJ9 was used as probe (Fig. 5c), except that no homology was detected with the $\mathrm{Cm}^{\mathrm{r}}$ plasmid of strain A82 (lane D). pRJ9 showed strong homology with $\mathrm{pRJ} 10$ and $\mathrm{pRJ} 11$ (lanes B and D) and weaker homology with pRJ6 (lane C). This is consistent with the restriction analysis of these plasmids.

In Fig. 5(b) and (c), lanes A, B and D, it appears that the chromosomal bands also hybridized with pRJ6 or pRJ9. However, this hybridization can be attributed to the OC forms of plasmids pRJ9, pRJ10 and pRJ11 comigrating with the chromosomal fragments.

\section{Conclusions}

The six bacteriocinogenic plasmids carried by the $S$. aureus strains we studied could be separated into two groups: (i) plasmids larger than $40 \mathrm{~kb}$ which code for a high- $M_{\mathrm{r}}$ bacteriocin and that do not confer immunity, and (ii) small plasmids (8.0-10.4 kb) which code for bacteriocins or bacteriocin-like substances with a low $M_{\mathrm{r}}$ and that also confer immunity.

The large plasmids we isolated do not specify either ETA or ETB, and were found in clinical isolates from phage groups I and/or III. The bacteriocins specified by these plasmids produced small zones of inhibition, limited to a few species of Gram-positive bacteria. The small plasmids were found in strains isolated from food and the bacteriocins or bacteriocin-like substances specified by them produced large zones of inhibition on a broader range of strains. The lack of detectable homology between plasmids pRJ6 or pRJ9 and the large Bac plasmids confirmed that the latter constitute a distinct group.

Two groups were differentiated among the four strains harbouring small Bac plasmids, on the basis of differences in the cross-immunity patterns, in the chemical characteristics of their bacteriocins and in the physical analysis of their Bac plasmids. The first group comprises strains A53, A65 and A82, whose bacteriocin-like substances have similar properties and are specified by closely related plasmids of $10.4 \mathrm{~kb}$. Moreover, these strains are not sensitive to bacteriocins produced by strains of the same group, but become susceptible to them after elimination of the Bac plasmid. The second type is defined by strain A70, the producer of a bacteriocin with distinct chemical properties which is specified by a smaller plasmid of $8.0 \mathrm{~kb}$. This plasmid, although different from the others, shares regions of sequence homology with them. Experiments to define the extent of homology between these small Bac plasmids, and to determine their incompatibility relationships and their genetic organization, are currently in progress.
We would like to thank Dr Mary O'Reilly, Dr Ellen Murphy, Dr Marvin Rogolsky and Dr Peter Pattee for providing strains, Dr Y. Piémont for supplying antisera, Dr A. M. Uthida-Tanaka for phage typing our strains and Dr C. Maia for supplying the $\left[\alpha^{-32}\right.$ P $]$ dATP. We are also indebted to Dr Ellen Murphy for the critical reading of this manuscript. This work was supported by grants from $\mathrm{CNPq}$ (Brazil) to both M.C.F.B. and E.G.C.P.

\section{References}

ANTHONY, B. F., Giuliano, D. M. \& OH, W. (1972). Nursery outbreak of staphylococcal scalded skin syndrome. American Journal of Diseases of Children 124, 41-44.

ArbuthnotT, J. P. \& Billcliffe, B. (1976). Qualitative and quantitative methods for detecting staphylococcal epidermolytic toxin. Journal of Medical Microbiology 9, 121-210.

Bastos, M. C. F. \& MuRPhy, E. (1988). Transposon Tn554 encodes three products required for transposition. EMBO Journal 7 , 2935-2941.

Bastos, M. C. F. \& Penido, E. G. C. (1981). Transduction in Staphylococcus aureus. II. Isolation of plasmids coding for drug resistance. Brazilian Journal of Genetics 4, 41-53.

Bastos, M. C. F., Bonaldo, M. C. \& Penido, E. G. C. (1980). Constitutive erythromycin resistance plasmid in Staphylococcus aureus. Journal of General Microbiology 121, 513-516.

Chopra, I., BennetT, P. M. \& LAceY, R. W. (1973). A variety of staphylococcal plasmids present in multiple copies. Journal of General Microbiology 79, 343-345.

DAJANI, A. S. \& TAUBE, Z. (1974). Plasmid-mediated production of staphylococcin in bacteriophage type 71 Staphylococcus aureus. Antimicrobial Agents and Chemotherapy 5, 594-598.

Dajani, A. S. \& Wannamaker, L. W. (1969). Demonstration of a bactericidal substance against $\beta$-hemolytic streptococci in supernatant fluids of staphylococcal cultures. Journal of Bacteriology 97, 985-991.

Dajani, A. S., Gray, E. D. \& Wannamaker, L. W. (1970). Bactericidal substance from Staphylococcus aureus. Biological properties. Journal of Experimental Medicine 131, 1004-1015.

Ersfeld-Dressen, H., SaHL, H. G. \& Brandis, H. (1984). Plasmid involvement in production and immunity to the staphylococcin-like peptide Pep 5. Journal of General Microbiology 130, 3029-3035.

Gagliano, V. J. \& Hinsdill, R. D. (1970). Characterization of a Staphylococcus aureus bacteriocin. Journal of Bacteriology 104, 117-125.

Gross, D. C. \& Vidaver, A. K. (1978). Bac-like substances produced by Rhizobium japonicum and other slow-growing rhizobia. Applied and Environmental Microbiology 36, 936-943.

HARDY, K. G. (1975). Colicinogeny and related phenomena. Bacteriological Reviews 39, 464-515.

JetTen, A. M. \& Vogels, G. D. (1972). Nature and properties of a Staphylococcus epidermidis bacteriocin. Journal of Bacteriology 112, 243-250.

Jetten, A. M. \& Vogels, G. D. (1973). Characterization and extrachromosomal control of bacteriocin production in Staphylococcus aureus. Antimicrobial Agents and Chemotherapy 4, 49-57.

Jetten, A. M., Vogels, G. D. \& Windt, F. (1972). Production and purification of a Staphylococcus epidermidis bacteriocin. Journal of Bacteriology 112, 235-242.

Joseph, M. U., Desai, J. D. \& Desai, A. J. (1983). Production of antimicrobial and bacteriocin-like substances by Rhizobium trifolii. Applied and Environmental Microbiology 45, 532-535.

Maniatis, T., Fritsch, E. F. \& SambrooK, J. (1982). Molecular Cloning: a Laboratory Manual. Cold Spring Harbor, NY: Cold Spring Harbor Laboratory.

Masterson, R., Von David, W., Wiley, B. B. \& Rogolsky, M. (1983). Mutagenesis of extrachromosomal genetic determinants for ETB and BacR1 synthesis in Staphylococcus aureus after plasmid transfer by protoplast fusion. Infection and Immunity 42, 973-979. 
Nakamura T., YamaZaki, N., TANiguchi, H. \& Fujimura, S. (1983). Production, purification and properties of a bacteriocin from Staphylococcus aureus. Infection and Immunity 39, 609-614.

Novick, R. P. (1967). Properties of a cryptic high-frequency transducing phage in Staphylococcus aureus. Virology 33, 155-166.

Novick, R. P. \& Bouanchaud, D. (1971). Extrachromosomal nature of drug resistance in Staphylococcus aureus. Annals of the New York Academy of Sciences 182, 279-294.

Novick, R. P., Edelman, I., Schwesinger, M., Gruss, A., Swanson, E. \& Pattee, P. (1979a). Genetic translocation in Staphylococcus aureus. Proceedings of the National Academy of Sciences of the United States of America 76, 400-404.

Novick, R. P., Murphy, E., Gryczan, T. J., Baron, E. \& Edelman, I. (1979b). Penicillinase plasmids of Staphylococcus aureus: restriction-deletion maps. Plasmid 2, 109-129.

O'Reilly, M., Dougan, G., Foster, T. J. \& Arbuthnott, J. P. (1981). Plasmids in epidermolytic strains of Staphylococcus aureus. Journal of General Microbiology 124, 99-107.

PARKer, M. T. \& Simmons, L. E. (1959). The inhibition of Corynebacterium diphtheriae and other Gram-positive organisms by Staphylococcus aureus. Journal of General Microbiology 21, 457-476.

PATTEE, P. (1981). Distribution of Tn551 insertion sites responsible for auxotrophy on the Staphylococcus aureus chromosome. Journal of Bacteriology 145, 479-488.
ReEves, P. (1972). The Bacteriocins. Molecular Biology, Biochemistry and Biophysics, vol. II. New York: Springer-Verlag.

RogolsKy, M. \& WiLeY, B. B. (1977). Production and properties of a staphylococcin genetically controlled by the staphylococcal plasmid for exfoliative toxin synthesis. Infection and Immunity 15, 725-732.

Schwinghamer, E. A. (1975). Properties of some bacteriocins produced by Rhizobium trifolii. Journal of General Microbiology 91, 403-413.

TAGG, J. R., Dajani, A. S. \& Wannamaker, L. W. (1976). Bacteriocins of Gram-positive bacteria. Bacteriological Reviews 40, 722-756.

W ARREN, R. L. (1980). Exfoliative toxin plasmids of bacteriophage group 2 Staphylococcus aureus: sequence homology. Infection and Immunity 30, 601-606.

WarRen, R., RogolsKy, M., WILEy, B. B. \& Glasgow, L. A. (1974). Effect of ethidium bromide on elimination of exfoliative toxin and bacteriocin production in Staphylococcus aureus. Journal of Bacteriology 118, 980-985.

Warren, R., Rogolsky, M., Wiley, B. B. \& Glasgow, L. A. (1975). Isolation of extrachromosomal deoxyribonucleic acid for exfoliative toxin production from phage group II Staphylococcus aureus. Journal of Bacteriology 122, 99-105. 